Amin, Z., Burhanuddin, B., Shadiq, T. F., \& Purba, A. S. (2021). What academia say on university choices in achieving the future goals of studying abroad: meta-analysis. International Journal of Social Sciences,4(1), 114-121. https://doi.org/10.31295/ijss.v4n1.1415

\title{
What Academia Say on University Choices in Achieving the Future Goals of Studying Abroad: Meta-analysis
}

\author{
Zulkifli Amin \\ Universitas Muhammadiyah Sumatera Utara, Indonesia \\ Corresponding author email: zulkifliamin@umsu.ac.id \\ Burhanuddin \\ Universitas Muhammadiyah Sumatera Utara, Indonesia \\ Email: burhanuddin@umsu.ac.id \\ Teuku Fajar Shadiq \\ Universitas Islam Syekh Yusuf Tangerang Indonesia \\ Email: teuku_fajarshadiq@unis.ac.id \\ Anwar Soleh Purba \\ Universitas Islam Sumatera Utara, Indonesia \\ Email: anwarsolehpurba12@gmail.com
}

\begin{abstract}
This paper aimed to understand what the academic elites think about the student's university decision process and achieve students' future goals from studying at foreign universities. Because the success of studying abroad is believed to be closely related to the process of selecting university candidates with all the advantages and prestige of each university offered during recruitment promotions, to understand this, we searched for data sources electronically from various international journals and promotional advertisements. We processed this in a phenomenological approach that begins with understanding the problem and the study's hypothesis-the coding system, evaluation, and in-depth interpretation to get the findings'validity and reliability. Our data sources are based on Google Scholar, Microsoft Academic, and other sources from 2010 to 2021. Based on the results of the discussion of the findings data, we can conclude our findings, among others. The decision to study abroad is first beginning with the right subject, course content, sports and societies, student accommodation, and scholarship availability. To get that information, applicants have to research alumni meetings, scholarship tours and promotions, western or eastern countries, and use multiple information sources. Thus, these findings should help prospective students and universities explore prospective international students' advertisements.
\end{abstract}

Keywords---academics advice, future goals, study abroad, university advantages.

\section{Introduction}

To attract potential students both from within and outside the country, every important university has a deep understanding of how prospective students select and decide which university candidates they are most interested in (Velliaris, 2016). Likewise, prospective students must have a clear understanding of the path and process of determining which university they will choose because the existence of the university they choose is the main instrument with all the potential of the university so that prospective students can develop the right way and strategy for choosing a university (Trower \& Lehmann, 2017). Because by choosing the right pathway, students must understand the university's matrix because it will affect a destination abroad selection process. As it is understood 
that choosing the best university is not an easy matter because it involves how well a person understands global education issues and local issues and the challenges around them (Hemsley-Brown, 2012).

Admittedly, many studies present the university choice criteria used by prospective students to determine a college or university. However, very few can understand how to fulfill all the main priorities and criteria that match expectations in the university's choice that answers students' future challenges. For this reason, this review will lead to an in-depth understanding by presenting the findings from the opinions of academic leaders in the country or university where the study is headed. We will describe the chosen model of excellence and competitiveness of the universities that we studied through qualitative references and review of international publications (Ter Bogt \& Scapens, 2012; Balconi et al., 2004; Bjerregaard, 2010).

Why is it essential to think about employability factors when students choose the university they want? Jackson, (2010) said that the understanding of prospective students is fundamental about prospective universities' employability. This is because employability and job prospects are among the glaring but obscure common issues universities use in their limited time grants to support their enrolment. Often when universities promote the university, they always prioritize the employability of their alumni. However, sometimes they do not understand what they say in promos for prospective students. As shown by a study led by Times Higher Education in 2017, (Stokes, 2017; Cook et al., 2006; Kause et al., 2004) employability may be a significant component of students going to college. More than a portion of the members announced that they were going to college to find specific jobs. For the Times Higher Education study, employability includes three main components: college alumni employability rates, professional administration, and connections with providers and recruits. Thus, employability goes beyond employment possibilities.

Additional employability factors that are necessary for students to understand include: preparing students for long-term job performance. Demonstrates students the relational and expert skills they need to win at their jobs. (Helyer \& Lee, 2014; Miyazaki \& Islam, 2007; Zilahy \& Huisingh, 2009). Ensuring students are "job-ready" when they graduate-implementing different programs and activities to provide professional support for students. Even though colleges can promote high employability ratings in their statement of purpose, that may not mean much in general. Students will need to do their portion check to survey upcoming college job vacancies. When deciding to go to college, students need to consider additional reasonable factors - and often overlooked - factors in addition to each one of those business insight factors. Harvey et al. (2017) noted that student equity understanding and working employability as they depart in higher education should be a government priority in providing higher education and human resource training.

The information should include accessibility of mechanical situations, temporary positions, excursion vacancies, joining businesses, professional administration, extracurricular training, local area commitments, support for business ventures, accessibility of industrial placements, and other exciting positions (Scheef et al., 2018). Just like students are not everyday work experience. This kind of information arrangement - sometimes called the "sandwich situation" - really makes up part of the college course. Students may take 9 to 13 months to complete. Understudies are regularly interested in mechanic positions during their final year of study. This position can help support the ability to survive while getting any job quickly (Sternberg, 1997).

Another understanding, for example, how the choice of target university is to have the capacity to build student expertise organization. Thus, the university can expand future student candidates' potential benefits. (Hoxby \& Turner, 2013). For example, the ability to provide employment insights in the student's chosen field. Universities can make better decisions about their profession and expertise. Universities usually offer an understanding of vocational ways that better qualify students' abilities and expertise. When evaluating the opening of a university's modern era, the university must consider whether its mechanical arrangement is to be all-assured or initially to begin serving students, not just because of the opportunity to gain unilateral paid benefits. Universities should be open to students all over the world (Kirzner, 2015). Students can join with extra help.

The latest degree results can be relevant to the demands of the professional world. Students can work even though it is temporary and work experience opportunities on holidays to improve their work abilities outside of work time. This is because taking part in temporary employment or work experience opportunities during the winter years and the end of the spring month is an excellent method for building student expert skills at western universities. So that universities can prepare their alumni for changes in the world of work (Baird, 2015).

Compared to the world of work in the student's home country, the temporary world of work in the country the student aims for should have more fantastic opportunities because, with limited work experience, students can have the opportunity to work on vacation. Even if only a few weeks during a quarter of the year. (Helyer \& Lee, 2014). This provisional plan can help prospective alumni set up compatibility with possible managers or aspiring professional guides like any mechanical work situation. A concrete example, for example, is the availability of a 
college relationship with prominent employers. Since the college has a decent position, it does not mean that the college has a strong business relationship. When making decisions about studying at a university, students can consider whether they plan to work closely with the job manager. Students should pay attention to job fairs, organizing events, work experience openings, workshops and business associations, and comparison events. Opportunities like this will help students build networks with potential leaders who have a strong relationship with the college they are aiming for, then expand students' opportunities to gain job insights and eventually get a job (Rivera, 2015).

\section{Careers Services}

Benbow \& Lee (2019) state that most Western colleges offer a vocation guide administration or an employability focus to assist students with professional advancement. However, the level of assistance and administration offered can fundamentally fluctuate between different institutions. The administration offered regularly includes CV workshops, job form centers, and vocation appraisals opening. Understudies can also meet on-call advisors who can provide tailor-made advice and support. Even though job services can help put students on the right professional path, it would not be wise to rely on these services alone if students hope to find the dream job students want. Comprehension must step onto the plate and enhance their employability by sharpening their expert skills and "subtle" abilities (Dougherty \& Lombardi, 2016).

\section{Entrepreneurship Mindsets}

Extracurricular engagement programs and the advanced ability community will only lead students to workforce readiness (Gribble et al., 2017). The university's readiness is inclined to prepare balanced alumni interested in their clients and work networks and build extraordinary relationships that will be why students choose such a university. Joining and studying with the explicit goal of a cooperative environment and taking part in a social setting or a potential sports club is an excellent approach to building subtle skills valued by the world of business and industry (Royster et al., 2015). This open group of people commitment can show students collaboration, critical thinking, relational skills, and more. Even though this is the best timing approach to assist student employability, they will make friends with comparative interests and goals-seemingly mutually beneficial. The examples above are the essential points that must be the criteria when students choose college goals. Likewise, the above matters will be the main points for developing each university's uniqueness (Morris et al., 2013).

Based on the importance of understanding how the university will benefit students' future, this study is essential to carry out. Blake \& Gallimore (2018) noted that understanding academic potential is an important research project before deciding on a university to enter. Because educational institutions such as universities are developed to train skills that prioritize student excellence needed in fostering the careers and work lives of their respective alumni excellence in communication, work organization, time management, teamwork collaboration, leadership, critical thinking, and efforts to increase the intellectual potential and increase alumni income, all of this will be achieved if have a prospective academic degree that will make alumni more attractive to industry and employers, so that students will have more job choices.

They will get more (Tymon, 2013) suppose a student is looking for a college like the above criteria. In that case, students will consider various aspects, such as location, campus size, overall cost, quality of academic services, campus safety and comfort, choice of particular majors, and other factors that are important to pay attention to. Students should consider the following points with many important factors when choosing a college because all considerations will help students themselves when they want their higher education to positively impact the future of work careers, the quality of alumni, and economic development improvement. Finally, searching for an in-depth understanding of selecting prospective universities abroad will be directed and easy (Carothers, 2010).

\section{Method}

In this section, we will explain how this study tried to answer the questions of this study. As explained in the beginning, this review study aimed to gain a specific, in-depth understanding of what university leaders are doing in the process of convincing prospective international students so that they want to choose the university they manage for their reasons in order to achieve the educational goals and future work of students from the service study at a foreign university. The reason is, the great success of studying at prestigious overseas universities is believed to be closely related to the decision-making process by university candidates with all the advantages and prestige of each 
university that advertises itself during the promotion session for the recruitment of prospective applicants. For that, we have searched electronic data sources from various international journals and promotional advertisements. Then we process it in a descriptive approach that begins to understand the questions and research hypotheses through coding system, short evaluation, and in-depth interpretation to get the validity and reliability of the findings. Our data sources are based on Google Scholar, Microsoft Academic, and other sources from 2010 to 2021 so that the data we study are up to date and accurate. All processes we follow the direction of a qualitative review study expert in overseas higher education studies Thomas et al. (2014) in his study "A qualitative review of literature on peer review of teaching in higher education: An application of the SWOT framework."

\section{Findings}

In this section, we are going to present only the findings from study goal that wish to get deep understanding and reasonable factor why students need to consider ideas for recognized academia idea about some basic thoughts before departing their oversea postgraduate study when they want to gain employability and competitive alumni from the recognized university they intend to enter.

The first review is Rekhter \& Hossler (2020) where Russian students use social networking sites to choose universities abroad. This is proven through a case study at the Russian State University for the Department of Humanities. The understanding that comes from the study of the Russian State University for the Humanities, which uses the location of long-distance interpersonal communication for their choice of transfer to further education universities abroad, is exact. Prospective students have used specific means, such as 'like' and 'comments,' to measure Higher Education Institutions' ranking (HEIs). Members with overseas associations rely on guidance from global contacts, and prospective students take part accordingly. HEI specialists may consider hiring and preparing prospective global students to maintain predictable and significant content at different tertiary entry stages outside the country. A similar study was also carried out (Zhu, 2019) which used social networking engagement by Chinese students outside of student recruitment countries to understand how United Kingdom HEIs use Weibo and the WeChat application.

Wu (2014) proved how Chinese students' inspiring and dynamic interaction is to take courses and expertise abroad. Territory Chinese students travel overseas to seek postgraduate courses, but the reasons do not adequately consider the majors and other tertiary institutions' existence. We examine inspiring regional Chinese students to choose UK courses and study areas. More experienced students and individuals taking MA programs are more influenced by need due to searching for information to find alternative options. However, the accuracy of younger students and students taking the MSc program is determined more by the factors identified with scholastic quality, not cultural pursuits, and outside academics. This study's essence is the importance of seeking university uniqueness information that will determine and assist university candidates' choice. The same study was also carried out by Selingo (2013) who said that universities are bound for the future formation of higher education and what it means for prospective students.

Levesque \& Mallard (2015) examined the rules students use to choose universities abroad through a contextual study of what factors students worldwide use to choose foreign universities to concentrate on abroad. To attract global students, universities need to develop a competitive promotion methodology. Comprehension seeks extraordinary university excellence and enhances the transfer of knowledge and expert expertise of students. Comprehension must assess the options offered to them, and due to various factors of determination, students will make their final decision. This study adds to the understanding of inspiring students to concentrate abroad and determines the various elements they consider in choosing their college. Important information is gathered in the college where the creator is considering the year via an overview and multiple meetings. Information inquiries about university excellence are distributed in an online version updated daily on the theme "Continuing Education and a Skilled and outward-looking Developing World." Standley (2015) also proved a similar study, which said the importance of international student mobility for placements to enable students at the best universities to enhance transversal and employability-related skills in the global context.

$\mathrm{Lu}$ (2017) study explores Chinese international doctoral students' inspiration to take Ph.D. degrees abroad. For the current situation, seeking understanding in higher education and self-development appears to be the most tangible individual and collective inspiration. However, the decision to study and concentrate abroad ultimately the choice of many individuals are influenced by the university's scope of the information component. Likewise, both academic and individual managers take an essential part in the choice of host university organization, with information readiness for prospective students being of prime importance. This study investigation may be helpful for administrators and producers of different education strategies in carrying out their roles in serving international 
demands in guaranteeing the quality of higher education services. (Cho \& Price, 2018) where services are ways to bridge constraints for prospective students in the search for competitive activities and Intramural Sports with a comparison of international and domestic students.

Zwart (2013) studied how Chinese students decided to study abroad; factors, impact, and inspiration behind their university clear college campus choice. This investigation looked at the factors that spurred Chinese students to choose or reject English-speaking countries such as Australia, Canada, the United States, and the United Kingdom for studying abroad. This study finds that at least two factors most influence state objectives, namely higher education institutions' position and the average cost for basic expenses and education costs. The least significant factor is the opportunity for migration to the host country. The reactions differ depending on the segment information, most notably, financial status. This study's findings are Chinese students' decision to study in Englishspeaking countries, especially the position, funding, and quality factors offered by the university. A similar study was also carried out by Padlee et al. (2010) who found out how international students' choices and behavior in higher education at public and private universities in Malaysia.

Hasan (2019) noted that the number of countries involved in new student enrollments worldwide has recently proliferated. This indicates that it is increasingly important to understand better the factors influencing the choice of study destinations for international students. Information such as potential, which the accepting university students own, is crucial because it involves the planning aspects of a correspondence and registration system that is suitable for higher education institutions to attract global students. The measurement of information variation is carried out through semi-organized meetings of current or postgraduate expert students who are considering or have been concentrated in Sweden and the University of Gothenburg staff in influencing student choice around the world. They include correspondence, environmental and social elements. Ith selection of exam objectives is felt to be very important (Brimmer, 2018).

George III (2021) proves that the trend of a competitive education climate and the high interest of international students are increasingly significant for other education organizations that call for and compete in a country's educational service methodology, which shows that competitive educational services provide the best. So they are world universities targeting to increase understanding of how global students choose the right higher education institutions. They further extended the hypothetical structures for advertising in their higher education and constructed a system of plausible choice cycles that details the stages and factors that apply to these choices, such as inspiration to leave the country of birth, data sources, and choice variables. Prospective students study how global students choose foreign universities abroad. The results suggest significant consequences for higher education institutions in planning projects to attract students worldwide. The model created establishes a complete systematization of the decision cycle to capture as many prospective students from abroad (Le, 2014).

Seligman et al. (2017) note that the study is essential to identify foreign universities' variables that inspire influencing international students' choice to concentrate in the United States. The study applies and describes a subjective way for contemporary prospective students to carefully identify orientation meeting notes to ascertain the decision factors and their significance on why they chose an overseas university. Inductive investigations are used to generate objective decision models for students worldwide depending on the push and pull model move choices. Three driving variables and three power factors are resolved to influence state and university decisions. Academic quality, the prospect of collaboration with industry, and the university's reputation are fundamental issues of the main components that every international student must understand before making decisions on their future university candidates. This is similar to the study (O'Loughlin, 2013).

One of the most important findings for understanding the existence of a university student's choice of candidate is Petruzzellis \& Romanazzi (2010) study. This study looks at the quality and instructive value. This means that how students choose tertiary institutions begins with the quality score of teaching services. Instructive administration books from universities around the world can do this. Their study hopes to measure students' views about significant value affected by differences in costs (financial and non-monetary related). This is seen in research on the college price segment, which influences student decisions. These findings suggest that, although universities can improve the maintenance of students seeking to expand their degree of fulfillment, their efforts will be more successful if the universities demonstrate how the administration provided has helped their prospective student clients achieve their goal of selecting a university that suits them well from the point of teaching services as well as tuition fees. This is evidenced by Rovai \& Downey (2010) who question why many distance universities often fail to achieve both terms (teaching services and fees) while face-to-face universities succeed at the global world level. 


\section{Discussion}

In this discussion section, we will present the main points of the review of several paper articles that discuss what high-level academics are doing about why prospective international students have reasons to choose the university they lead. In general, they argue that in order to achieve future goals, prospective students study abroad.

In general, it can be said that there are several main reasons why prospective students should choose the tertiary institutions they manage, which on average, are in English-speaking countries. The reason is, for example, that every university they build is a university that is more than just higher education. This means that universities provide extensive knowledge, re-skills, high self-confidence, and experience in supporting prospective students to become leaders in their world with opportunities and allowing students to take control of a better future. Besides, they said, tertiary institutions have higher education qualifications that make students more attractive to prospective employers and improve their economic level, increase their ability and self-motivation to pursue higher levels, and have a dedication to see. Their lectures through future orientation. In addition, each university promises career prospects for prospective students with high job skills, student personal development universities, the opportunity to advance in work with very flexible teaching, learning, research options. Similar issues were also proved by Jiani (2017) in the study reasons and the ways international participants choose China higher education abroad destination.

Of the ten articles we reviewed above, they, on average, have reasons that they call superiority, making them the university that prospective students should choose when they want to study abroad. The reason is that the academic culture is different from multiple nationalities, making their campuses an advantage when studying abroad, which is an opportunity to immerse oneself in an academic environment that is very diverse but still harmonious. Other reasons, for example, with superior quality education services, new language opportunities, academic career opportunities, new friends, international experience, opportunities to be independent. They also identify reasons for segmenting student decisions such as affordability of funds, availability of competitive majors, academic reputation, job opportunities, education supported by scholarships, international relations, bilateral relations, and prospective supervisors' availability. Heinz (2015) also asks the reasons for choosing universities with the quality of teaching. (Hifza et al., 2020; Hifza \& Aslan, 2020). Through international studies, empirical studies highlight students' careers and the level of motivations for their commitment to teaching students.

\section{Conclusion}

Based on the review results, several publications highlight the understanding of what campus researchers provide to prospective students who choose to study at foreign universities because students have a suitable program offered with the development of career learning and future work. So it can be concluded that prospective students' decision to study abroad is starting with a review of the lesson program that matches the scholarship and expertise of the prospective student. The teaching program's content follows this, the strength of the research, the university's reputation with a strong alumni association, the location and ease of accommodation, and the ease of scholarships. This information requires that prospective applicants review alumni associations, promotional tours, target Englishspeaking countries, using various online information sources. Thus, this review study's findings can help prospective applicants study abroad and universities who wish to invite prospective students abroad to study without borders.

\section{Acknowledgments}

We thank all colleagues for their support from the start of the planning period to the compilation and completion of writing with helpful feedback. Likewise, supporting departmental funds, so that helped us carry out this study with the theme "What Academia Say on University Choices in Achieving the Future Goals of Studying Abroad: MetaAnalysis."

\section{References}

Baird, B. N. (2015). Internship, practicum, and field placement handbook: A guide for the helping professions. Routledge.

Benbow, R. J., \& Lee, C. (2019). Teaching-focused social networks among college faculty: Exploring conditions for the development of social capital. Higher Education, 78(1), 67-89.

Balconi, M., Breschi, S., \& Lissoni, F. (2004). Networks of inventors and the role of academia: an exploration of Italian patent data. Research policy, 33(1), 127-145. https://doi.org/10.1016/S0048-7333(03)00108-2 
Bjerregaard, T. (2010). Industry and academia in convergence: Micro-institutional dimensions of R\&D collaboration. Technovation, 30(2), 100-108. https://doi.org/10.1016/j.technovation.2009.11.002

Blake, M., \& Gallimore, V. (2018). Understanding academics: A UX ethnographic research project at the University of York. New Review of Academic Librarianship, 24(3-4), 363-375.

Brimmer, E. D. (2018). Promoting inclusion in education abroad: A handbook of research and practice. Stylus Publishing, LLC.

Carothers, T. (2010). Promoting the rule of law abroad: In search of knowledge. Brookings Institution Press.

Cook, M. B., Bhamra, T. A., \& Lemon, M. (2006). The transfer and application of Product Service Systems: from academia to UK manufacturing firms. Journal of cleaner production, 14(17), 1455-1465. https://doi.org/10.1016/j.jclepro.2006.01.018

Cho, D., \& Price, T. (2018). Leisure Constraints to Participation in Competitive Activities and Intramural Sports: Comparing International and Domestic Students. Journal of International Students, 8(2), 884-900.

Dougherty, S. M., \& Lombardi, A. R. (2016). From vocational education to career readiness: The ongoing work of linking education and the labor market. Review of Research in Education, 40(1), 326-355.

George III, C. (2021). "Imfundo" the Student; the Evolution Adaptation, and Practice of African Centered Education at the Kara Heritage Institute in Pretoria South Africa $[\mathrm{PhD}$ Thesis]. Michigan State University.

Gribble, C., Rahimi, M., \& Blackmore, J. (2017). International students and post-study employment: The impact of university and host community engagement on the employment outcomes of international students in Australia. In International student connectedness and identity (pp. 15-39). Springer.

Harvey, A., Andrewartha, L., Edwards, D., Clarke, J., \& Reyes, K. (2017). Student equity and employability in higher education. Report for the Australian Government Department of Education and Training. Melbourne: Centre for Higher Education Equity and Diversity Research, La Trobe University.

Hasan, R. (2019). Factors affecting the Guardians Satisfaction \& Clientele of English Medium and English Version school and college of Dhaka city area in Bangladesh.

Heinz, M. (2015). Why choose teaching? An international review of empirical studies exploring student teachers' career motivations and levels of commitment to teaching. Educational Research and Evaluation, 21(3), 258-297.

Helyer, R., \& Lee, D. (2014). The role of work experience in the future employability of higher education graduates. Higher Education Quarterly, 68(3), 348-372.

Hemsley-Brown, J. (2012). 'The best education in the world': Reality, repetition or cliché? International students' reasons for choosing an English university. Studies in Higher Education, 37(8), 1005-1022.

Hifza \& Aslan. (2020). The Model of Competitive Advantage Development in Private Islamic Education Institutions dalam "BASA 2019: Proceedings of the Third International Seminar on Recent Language, Literature, and Local Culture Studies, BASA, 20-21 September 2019, Surakarta, Central Java, Indonesia. European Alliance for Innovation.

Hifza, Juliana, Palapa, A., Maskur, \& Aslan. (2020). The Strategic Foundation for Competitive Excellent Development in Integrated Islamic Primary Schools in Indonesia. International Journal of Advanced Science and Technology, 29(12s), 1747-1753.

Hoxby, C. M., \& Turner, S. (2013). Informing students about their college options: A proposal for broadening the expanding college opportunities project.

Jackson, D. (2010). An international profile of industry-relevant competencies and skill gaps in modern graduates. International Journal of Management Education, 8(3), 29-58.

Jiani, M. A. (2017). Why and how international students choose Mainland China as a higher education study abroad destination. Higher Education, 74(4), 563-579.

Kause, J., Smith, G., Prytherch, D., Parr, M., Flabouris, A., \& Hillman, K. (2004). A comparison of antecedents to cardiac arrests, deaths and emergency intensive care admissions in Australia and New Zealand, and the United Kingdom - the ACADEMIA 275-282. https://doi.org/10.1016/j.resuscitation.2004.05.016

Kirzner, I. M. (2015). Competition and entrepreneurship. University of Chicago press.

Le, A. (2014). Vietnamese international student repatriates: An exploratory study.

Levesque, N., \& Mallard, C. (2015). The criteria used by students to select a university abroad: A case study on which factors are used by the international studentsto select a foreign university for studyingAuthors.

Lu, Y. (2017). Chinese graduate international students'cultural adjustment in the us: a qualitative investigation [PhD Thesis].

Miyazaki, K., \& Islam, N. (2007). Nanotechnology systems of innovation-An analysis of industry and academia research activities. Technovation, 27(11), 661-675. https://doi.org/10.1016/j.technovation.2007.05.009 
Morris, M. H., Kuratko, D. F., \& Cornwall, J. R. (2013). Entrepreneurship programs and the modern university. Edward Elgar Publishing.

O'Loughlin, K. (2013). Developing the assessment literacy of university proficiency test users. Language Testing, 30(3), 363-380.

Padlee, S. F., Kamaruddin, A. R., \& Baharun, R. (2010). International students' choice behavior for higher education at Malaysian private universities. International Journal of Marketing Studies, 2(2), 202.

Petruzzellis, L., \& Romanazzi, S. (2010). Educational value: How students choose university. International Journal of Educational Management.

Rekhter, N., \& Hossler, D. (2020). Russian Students' Use of Social Network Sites for Selecting University Abroad: Case Study at the Russian State University for Humanities. Journal of International Students, 10(3), 724-740.

Rivera, L. A. (2015). Pedigree: How elite students get elite jobs. Princeton University Press.

Rovai, A. P., \& Downey, J. R. (2010). Why some distance education programs fail while others succeed in a global environment. The Internet and Higher Education, 13(3), 141-147.

Royster, P., Gross, J., \& Hochbein, C. (2015). Timing is everything: Getting students back on track to college readiness in high school. The High School Journal, 98(3), 208-225.

Scheef, A. R., Barrio, B. L., Poppen, M. I., McMahon, D., \& Miller, D. (2018). Exploring Barriers for Facilitating Work Experience Opportunities for Students with Intellectual Disabilities Enrolled in Postsecondary Education Programs. Journal of Postsecondary Education and Disability, 31(3), 209-224.

Seligman, L. D., Hovey, J. D., Chacon, K., \& Ollendick, T. H. (2017). Dental anxiety: An understudied problem in youth. Clinical Psychology Review, 55, 25-40.

Selingo, J. J. (2013). College (un) bound: The future of higher education and what it means for students. Houghton Mifflin Harcourt.

Standley, H. J. (2015). International mobility placements enable students and staff in Higher Education to enhance transversal and employability-related skills. FEMS Microbiology Letters, 362(19).

Sternberg, R. J. (1997). The concept of intelligence and its role in lifelong learning and success. American Psychologist, 52(10), 1030.

Stokes, P. J. (2017). Higher education and employability: New models for integrating study and work. Harvard Education Press.

Ter Bogt, H. J., \& Scapens, R. W. (2012). Performance management in universities: Effects of the transition to more quantitative measurement systems. European Accounting Review, 21(3), 451-497.

Thomas, S., Chie, Q. T., Abraham, M., Jalarajan Raj, S., \& Beh, L.-S. (2014). A qualitative review of literature on peer review of teaching in higher education: An application of the SWOT framework. Review of Educational Research, 84(1), 112-159.

Trower, H., \& Lehmann, W. (2017). Strategic escapes: Negotiating motivations of personal growth and instrumental benefits in the decision to study abroad. British Educational Research Journal, 43(2), 275-289.

Tymon, A. (2013). The student perspective on employability. Studies in Higher Education, 38(6), 841-856.

Velliaris, D. M. (2016). Choosing the right pathway: A matrix of influences related to selection of higher education destination abroad. In Global perspectives and local challenges surrounding international student mobility (pp. 179-200). IGI Global.

Wu, Q. (2014). Motivations and decision-making processes of mainland Chinese students for undertaking master's programs abroad. Journal of Studies in International Education, 18(5), 426-444.

Zhu, Y. (2019). Social media engagement and Chinese international student recruitment: Understanding how UK HEIs use Weibo and WeChat. Journal of Marketing for Higher Education.

Zilahy, G., \& Huisingh, D. (2009). The roles of academia in regional sustainability initiatives. Journal of Cleaner Production, 17(12), 1057-1066. https://doi.org/10.1016/j.jclepro.2009.03.018

Zwart, J. (2013). Study abroad choices of Chinese students: Factors, influences and motivations. Quarterly Journal of Chinese Studies, 2(2), 68. 